\title{
Rights-based family planning: 10 resources to guide programming
}

Jan Kumar

Karen Hardee

Population Council

Follow this and additional works at: https://knowledgecommons.popcouncil.org/departments_sbsr-rh

Part of the Demography, Population, and Ecology Commons, Family, Life Course, and Society Commons, International Public Health Commons, and the Women's Health Commons How does access to this work benefit you? Let us know!

\section{Recommended Citation}

Kumar, Jan and Karen Hardee. 2015. "Rights-based family planning: 10 resources to guide programming," Resource guide. Washington, DC: Population Council, The Evidence Project. 


\title{
Rights-Based Family Planning: 10 Resources to Guide Programming
}

\section{RESOURCE GUIDE}

\author{
Jan Kumar | Karen Hardee
}

May 2015 
The Evidence Project

Population Council

4301 Connecticut Ave. NW, Suite 280

Washington, DC 20008 USA

tel +12022379400

evidneceproject.popcouncil.org

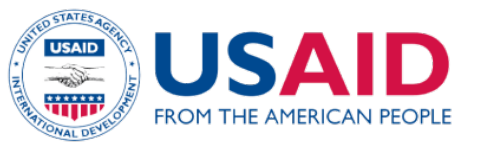

The Evidence Project is made possible by the generous support of the American people through the United States Agency for International Development (USAID) under the terms of cooperative agreement no. AID-

OAA-A-13-00087. The contents of this document are the sole responsibility of the Evidence Project and Population Council and do not necessarily reflect the views of USAID or the United States Government.

\section{Evidence}

The Evidence Project uses implementation science-the strategic generation, translation, and use of evidence - to strengthen and scale up family planning and reproductive health programs to reduce unintended pregnancies worldwide. The Evidence Project is led by the Population Council in partnership with INDEPTH Network, International Planned Parenthood Federation, Management Sciences for Health, PATH, Population Reference Bureau, and a University Research Network.

Published in May 2015.

Suggested citation: Kumar, Jan and Karen Hardee. 2015. "Rights-Based Family Planning: 10 Resources to Guide Programming,” Resource Guide. Washington, DC: Population Council, The Evidence Project.

C 2015 The Population Council, Inc. 


\section{Table of Contents}

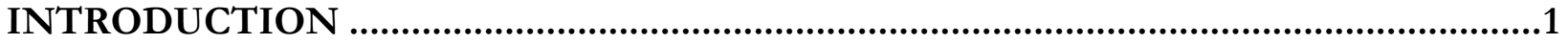

The Basis for Human Rights and Family Planning ....................................................................................

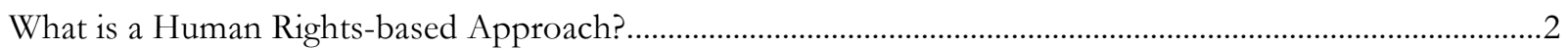

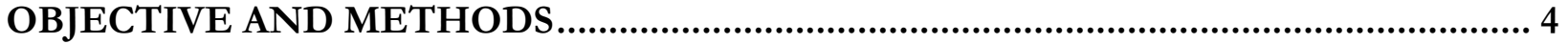

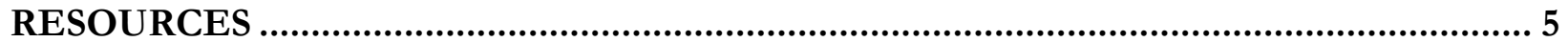

FP2020 Rights and Empowerment Principles for Family Planning......................................................................6

Ensuring Human Rights in the Provision of Contraceptive Information and Services....................................

Ensuring Human Rights Within Contraceptive Service Delivery: Implementation Guide ...............................9

Voluntary Family Planning Programs that Respect, Protect, and Fulfill Human Rights: A Conceptual

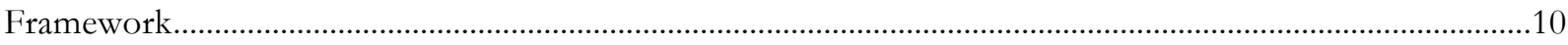

Voluntary Family Planning Programs that Respect, Protect, and Fulfill Human Rights: Conceptual

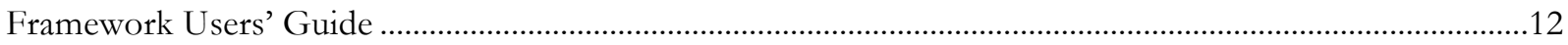

Checkpoints for Choice: An Orientation and Resource Package .....................................................................13

A Human Rights-Based Approach to Programming: Practical Implementation Manual and Training

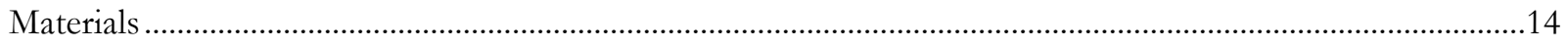

The Right to Contraceptive Information and Services for Women and Adolescents: Briefing Paper...........16

Voluntary Family Planning Programs that Respect, Protect, and Fulfill Human Rights: A Systematic

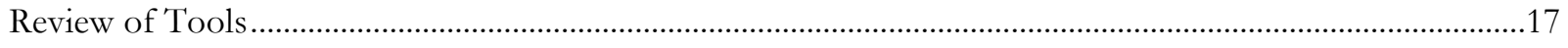

Reproductive Rights are Human Rights. A Handbook for National Human Rights Institutions...................18

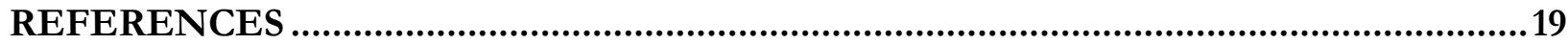




\title{
Introduction
}

\author{
THERE IS NO SINGLE HUMAN RIGHTS INSTRUMENT DEDICATED TO REPRODUCTIVE \\ RIGHTS. RATHER, THE MAIN UNITED NATIONS AND REGIONAL HUMAN RIGHTS \\ INSTRUMENTS PROTECT THE VARIOUS ELEMENTS OF REPRODUCTIVE RIGHTS. VARIOUS \\ DECLARATIONS AND SIMILAR DOCUMENTS ADOPTED BY CONSENSUS BY PRACTICALLY \\ ALL OF THE WORLD'S NATIONS AND FURTHER DEVELOPED IN THE PRACTICE OF THE \\ UNITED NATIONS AND REGIONAL HUMAN RIGHTS BODIES CONFIRM THE DIVERSE AND \\ RICH NATURE OF REPRODUCTIVE RIGHTS.
}

UNFPA, Danish Institute for Human Rights and UNOHCRH. 2014: 21.

The ambitious FP2020 goal of providing family planning services to 120 million more women and girls that emerged from the Family Planning Summit in London in 2012 has refocused attention on the need to ensure that family planning programs respect, protect and fulfill individual's human rights and that programs are implemented using a rights-based approach. The current challenge is how to operationalize human rights in existing family planning programs and the design of new projects. A number of resources are available to help stakeholders do so. The purpose of this paper is to review 10 key resources currently available to guide family planning programming.

\section{THE BASIS FOR HUMAN RIGHTS AND FAMILY PLANNING}

The human rights dimension of family planning programs has been recognized for nearly 50 years. People's right to decide freely and responsibly the number and spacing of their children and to have access to related information was asserted by the international community at the Conference on Human Rights in Tehran in 1968. This right has been reaffirmed and embellished by various bodies in numerous declarations and conventions over the years, notably the 1979 Convention on the Elimination of all forms of Discrimination Against Women (CEDAW), the 1994 International Conference on Population and Development (ICPD), and the 1995 Fourth World Conference on Women.

Following the ICPD in 1994, several organizations, including the International Planned Parenthood Federation and the Center for Reproductive Rights, articulated the foundation for human rights in family planning programs by identifying a dozen core human rights that underlie reproductive rights ${ }^{1}$ (IPPF, 1996; Center for Reproductive Rights, 2009). Cook and Erdman (2008), human rights attorneys, grouped these rights into three categories of reproductive rights:

- Those related to reproductive self-determination;

- Those related to access to sexual and reproductive health services, commodities, information and education; and

- Those related to equality and non-discrimination.

\footnotetext{
${ }^{1}$ These 12 rights are: The Right to Life; Liberty and Security of the Person; The Right to Equality, and to be Free from all Forms of Discrimination; The Right to Privacy; The Right to Freedom of Thought; The Right to Information and Education; The Right to Choose Whether or Not to Marry and to Found and Plan a Family; The Right to Decide Whether or When to Have Children; The Right to Health Care and Health Protection; The Right to the Benefits of Scientific Progress; The Right to Freedom of Assembly and Political Participation; and The Right to be Free from Torture and Ill Treatment.
} 
The Right to Health, as articulated in Comment 14, Article 12 of the International Covenant on Economic, Social and Cultural Rights, is a fundamental human right that applies in family planning programs. The Comment, a legally binding instrument, stipulates that governments are obligated to ensure that all healthcare information, services and commodities are available, accessible, acceptable and of the highest possible quality (commonly encapsulated in the acronym AAAQ).

In addition, there are principles that guide how family planning programs should be planned and carried out in order to respect, protect and fulfill these human rights. PANEL is a commonly accepted acronym, standing for Participation, Accountability, Non-discrimination and equality, Empowerment, and Links to the treaty bodies that make commitments legally binding.

While these rights and related principles are recognized by the international community and are increasingly a part of the discourse in family planning circles, a gap persists between the rhetoric of human rights and integrating these rights into family planning programming in actual practice. There is much talk about achieving universal access to high quality contraceptive information and services, and protecting clients' right to make full, free and informed contraceptive choices from among a range of options, but governments and programs still struggle with what a rights-based approach to family planning entails and how to operationalize it.

\section{WHAT IS A HUMAN RIGHTS-BASED APPROACH?}

Governments have legal obligations to respect, protect and fulfill human rights. At the same time, taking a human rightsbased approach to family planning can help ensure that human rights values and concepts are infused into all aspects of programming (Cottingham et al., 2012). Focusing on the reproductive rights that apply in family planning programs and the principles for how to design, implement, monitor and hold programs accountable to ensure that these rights are respected, protected and fulfilled should reorient how we approach programs. "There is no single definition of a human rights-based approach; however, taking such an approach for family planning includes the following (OHCHR, 2006; Gruskin, et al., 2007; UNFPA, 2010):

- Analyzing the inequalities related to family planning and reproductive health and the laws and policies under which programmes take place

- Ensuring that the plans, policies, and programs are anchored in a system of rights and corresponding obligations established by international law and that they integrate core buman rights principles such as participation, accountability, nondiscrimination, and empowerment

- Working toward equitable service delivery

- Focusing on key elements of the right to health-availability, accessibility, acceptability, and quality when defining standards for provision of services

- Empowering people themselves - especially the most marginalized-to participate in policy formulation and hold accountable those who have a duty to act" (Hardee et al., 2013). 
Rights-based programming places the individual's dignity and needs at the center. It provides the umbrella that pulls all program components together and adds additional value. Looking at a program through a human rights lens can help to identify program vulnerabilities, gaps or weaknesses that might not otherwise be recognized. It can reveal the unintended consequences of well-intentioned policies, practices and reporting requirements that are not informed by an awareness of human rights and the obligation to protect, respect and fulfill them. It can help stakeholders recognize the need to carry out ongoing activities differently, to invest in areas that might not currently be getting adequate attention (equity, empowerment, participation and accountability, for example), and/or to create strategic partnerships with stakeholders that are not typically engaged. 


\section{Objective and Methods}

How to move beyond the rhetoric to put a rights-based approach into action in family planning programs has been the subject of a number of resources published over the past few years. The proliferation of resources has caused some confusion among practitioners, who may be unclear about whether or not the resources address the same human rights, how they differ in approach, and how each resource could be used to guide family planning programming.

\section{AVAILABLE RESOURCES ON PROGRAMIMING HUMAN RIGHTS AND FAMILY PLANNING}

Available resources on rights-based programming for family planning vary in purpose, structure, scope and detail. They offer different frameworks and guidance; some are more comprehensive and programmatic than others. Faced with an abundance of resource documents, family planning stakeholders need help in deciding which to use for what purpose. This calls for a summary of key resources to foster understanding of how they compare to one another.

This paper addresses this need by annotating 10 documents using a consistent format that allows for easy comparison. It provides a description of each resource based on text drawn from the documents itself. The resources include human rights elements; principles and related recommended actions; comprehensive programming frameworks; how-to operational guidance; and tools that support rights-based FP programs.

The intention of this review is to provide an overview of key, recent publications to enable potential users to make an informed determination of what to apply to best meet their needs.

\section{SELECTION CRITERIA}

This review does not cover all existing materials related to a rights-based approach to family planning. Rather, it captures key resources with global applicability published since 2010 that support rights-based family planning programming. It does not cover the full spectrum of resources that are specific to related issues, such as empowerment, community engagement, informed choice, quality of care, program monitoring, and accountability mechanisms, among others.

Table 1 shows a list of the resources included in the paper. 


\section{Resources}

TABLE 1 List of Resources Included in the Paper

\begin{tabular}{|c|c|c|c|c|}
\hline & TITLE & YEAR & PUBLISHER & PAGE \\
\hline 1 & $\begin{array}{l}\text { FP2020: Rights and Empowerment } \\
\text { Principles for Family Planning }\end{array}$ & 2014 & FP2020 & 6 \\
\hline 2 & $\begin{array}{l}\text { Ensuring Human Rights in the Provision of } \\
\text { Contraceptive Information and Services }\end{array}$ & 2014 & WHO & 7 \\
\hline 3 & $\begin{array}{l}\text { Ensuring Human Rights Within } \\
\text { Contraceptive Service Delivery: } \\
\text { Implementation Guide }\end{array}$ & 2015 & WHO \& UNFPA & 9 \\
\hline 4 & $\begin{array}{l}\text { Voluntary Family Planning Programs that } \\
\text { Respect, Protect, and Fulfill Human Rights: } \\
\text { A Conceptual Framework }\end{array}$ & 2013 & Futures Group \& EngenderHealth & 10 \\
\hline 5 & $\begin{array}{l}\text { Voluntary Family Planning Programs That } \\
\text { Respect, Protect, and Fulfill Human Rights: } \\
\text { Conceptual Framework Users' Guide }\end{array}$ & 2014 & Futures Group \& EngenderHealth & 12 \\
\hline 6 & $\begin{array}{l}\text { Checkpoints for Choice: An Orientation } \\
\text { and Resource Package }\end{array}$ & 2014 & $\begin{array}{l}\text { EngenderHealth/the RESPOND } \\
\text { Project }\end{array}$ & 13 \\
\hline 7 & $\begin{array}{l}\text { A Human Rights-Based Approach to } \\
\text { Programming: Practical Implementation } \\
\text { Manual and Training Material }\end{array}$ & 2010 & $\begin{array}{l}\text { UNFPA with the Harvard School } \\
\text { of Public Health }\end{array}$ & 14 \\
\hline 8 & $\begin{array}{l}\text { The Right to Contraceptive Information and } \\
\text { Services for Women and Adolescents: } \\
\text { Briefing Paper }\end{array}$ & 2010 & $\begin{array}{l}\text { Center for Reproductive Rights } \\
\text { and UNFPA }\end{array}$ & 16 \\
\hline 9 & $\begin{array}{l}\text { Voluntary Family planning Programs that } \\
\text { Respect, Protect, and Fulfill Human Rights: } \\
\text { A Systematic Review of Tools }\end{array}$ & 2013 & $\begin{array}{l}\text { Futures Group and } \\
\text { EngenderHealth }\end{array}$ & 17 \\
\hline 10 & $\begin{array}{l}\text { Handbook for National Human Rights } \\
\text { Institutions: Reproductive Rights are } \\
\text { Human Rights }\end{array}$ & 2014 & $\begin{array}{l}\text { UNFPA, Danish Institute for } \\
\text { Human Rights, the Office of the } \\
\text { UN High Commissioner for } \\
\text { Human Rights }\end{array}$ & 18 \\
\hline
\end{tabular}




\section{FP2020 RIGHTS AND EMPOWERMENT PRINCIPLES FOR FAMILY PLANNING}

\begin{tabular}{|c|c|c|c|}
\hline DATE & PUBLISHER & LANGUAGES & FUNDING ORGANIZATION \\
\hline 2014 & FP2020 & English | French & FP2020 \\
\hline
\end{tabular}

TYPE OF RESOURCE

Human Rights Principles \& Program Guidance

\section{PURPOSE}

This brief is intended to establish a common understanding of rights principles as they relate to ten dimensions of family planning (FP). It can be used to heighten awareness of the essential elements of human rights that must be respected, protected and fulfilled in FP programs. It also offers broad direction regarding program design, monitoring, commodities, product and service promotion and sector engagement.

\section{INTENDED AUDIENCES/USERS}

A broad range of FP stakeholders, including donors, policymakers and program managers.

\section{SCOPE \& CONTENT}

Ten rights-related principles and FP program dimensions are defined, and for each one broad recommendations are offered for policy and programming, measurement and markets.
1. Agency and autonomy
6. Empowerment
2. Availability
7. Equity and non-discrimination
3. Accessibility
8. Informed choice
4. Acceptability
5. Quality
9. Transparency and accountability
10. Voice and participation

\section{DEVELOPMENT PROCESS}

This product was conceptualized and developed by FP2020's Rights \& Empowerment Working Group and informed by input from members of the FP2020 Country Engagement, Performance Monitoring \& Accountability and Market Dynamics Working Groups.

\section{HOW TO USE IT / RESOURCES REQUIRED}

This brief document frames essential human rights elements in FP programs in a concise manner. It can be used as a simple checklist and broad programmatic guide at a high conceptual level. No resources are required to use this document itself; however, additional guidance is necessary to operationalize its broad recommendations.

\section{WEB LINK}

English http://ec2-54-210-230-186.compute-1.amazonaws.com/wpcontent/uploads/2014/12/FP2020_Statement_of_Principles_FINAL.pdf

French http://ec2-54-210-230-186.compute-1.amazonaws.com/wpcontent/uploads/2014/12/FP2020_Statement_of_Principles_French_SinglePg_12.2.14.pdf 


\section{ENSURING HUMAN RIGHTS IN THE PROVISION OF CONTRACEPTIVE INFORMATION AND SERVICES}

\begin{tabular}{cccc}
\hline DATE & PUBLISHER & LANGUAGES & FUNDING ORGANIZATION \\
2014 & FP2020 & English | French | Spanish & WHO
\end{tabular}

\section{TYPE OF RESOURCE}

Program Guidelines \& Recommendations

\section{PURPOSE}

This document is designed to provide guidance on some of the priority actions needed to ensure that different human rights dimensions are systematically and clearly integrated into the provision of contraceptive information and services. It is structured around nine human rights standards and principles, for which it offers recommendations.

\section{INTENDED AUDIENCES/USERS}

Policy makers, managers, providers and other stakeholders in the health sector.

\section{SCOPE \& CONTENT}

The guidance recommends evidence-based interventions to support nine human rights components and principles:

1. Non- discrimination

2. Availability of contraceptive information and services

3. Accessibility of contraceptive information and services

4. Acceptability of contraceptive information and services

5. Quality of contraceptive information and services

6. Informed decision-making

7. Privacy and confidentiality

8. Participation

9. Accountability

It is considered a first step for addressing human rights obligations; it does not address all necessary FP program elements comprehensively. The intention is for it to be expanded and updated over time.

\section{DEVELOPMENT PROCESS}

The authors followed the WHO standards for guideline development. They identified priority questions and outcomes, and then retrieved, assessed and synthesized evidence using the systematic GRADE approach. This proved problematic for the topic, which doesn't lend itself to randomized controlled trials. The majority of the data couldn't be entered into the GRADE system. The authors developed narrative evidence summaries to fill gaps. They then drafted recommendations, which were reviewed and revised by a Guideline Development Group based on the evidence at a consultation.

\section{HOW TO USE IT / RESOURCES REQUIRED}

Any FP stakeholder can use this resource to inform their program. No special resources are required. 
WEB LINK

English http://apps.who.int/iris/bitstream/10665/102539/1/9789241506748_eng.pdf?ua=1;

http://apps.who.int/iris/bitstream/10665/102543/1/WHO_RHR_14.02_eng.pdf?ua=1

French http://apps.who.int/iris/bitstream/10665/126317/1/9789242506747 fre.pdf?ua=1\&ua=1

Spanish http://apps.who.int/iris/bitstream/10665/126318/1/9789243506746 spa.pdf?ua=1\&ua=1 
ENSURING HUMAN RIGHTS WITHIN CONTRACEPTIVE SERVICE DELIVERY: IMPLEMENTATION GUIDE

\begin{tabular}{|c|c|c|c|}
\hline DATE & PUBLISHER & LANGUAGES & FUNDING ORGANIZATION \\
\hline 2015 & WHO \& UNFPA & English & WHO \& UNFPA \\
\hline
\end{tabular}

\section{TYPE OF RESOURCE}

This implementation guide is a companion to the WHO's "Ensuring Human Rights in the Provision of Contraceptive Information and Services: Guidance and Recommendations" (2014), described above. It merges the recommendations that support nine principles and standards outlined by WHO with the content of UNFPA's “Choices not Chance: UNFPA’s Family Planning Strategy 2012-2020.”

\section{PURPOSE}

This document is designed to provide guidance on some of the priority actions needed to ensure that different human rights dimensions are systematically and clearly integrated into the provision of contraceptive information and services. It is structured around nine human rights standards and principles, for which it offers recommendations.

\section{INTENDED AUDIENCES/USERS}

This document is addressed to mid-level policymakers and program managers/implementers involved with family planning service provision in all settings.

\section{SCOPE \& CONTENT}

The guide "translates" the nine human rights standards laid out in the WHO guidance into corresponding programmatic concepts, or categories for program implementation. For each concept or category it provides introductory text, the related recommendations from the WHO guidance, and key considerations to think about and illustrative actions that could be taken. It also offers country examples of implementation of the recommendations. The Guide recognizes that additional actions are likely to be required for full implementation of the $\mathrm{WHO}$ recommendations. It highlights the importance of grounding all activities in the human rights principles of participation and accountability.

\section{DEVELOPMENT PROCESS}

This implementation guide was developed by identifying key considerations and action points for each of the WHO guidelines based on assessment and synthesis of evidence. An expert working group from UNFPA and WHO that included country-level programming experts reviewed the draft document and provided input. Human rights and gender equality principles were systematically incorporated in the development of the guide.

\section{HOW TO USE IT / RESOURCES REQUIRED}

Use of the guide does not require any special resources.

\section{WEB LINK}

http://apps.who.int/iris/bitstream/10665/158866/1/9789241549103_eng.pdf?ua $=1$ 


\section{4 \\ VOLUNTARY FAMIILY PLANNING PROGRAMS THAT RESPECT, PROTECT, AND FULFILL HUMAN RIGHTS: A CONCEPTUAL FRAMEWORK}

DATE

2013
PUBLISHER

Futures Group
LANGUAGES

English | French | Spanish | Hindi
FUNDING ORGANIZATION

The Bill and Melinda Gates

Foundation

\section{TYPE OF RESOURCE}

A comprehensive programming framework that details a vision for what a voluntary, rights-based family planning program entails at the policy, service delivery, community and individual levels.

\section{PURPOSE}

This is a practical programming tool that provides a vision of an ideal, holistic FP program that respects, protects and fulfills human rights expressed in programmatic terms. It can be used for:

- Increasing awareness and understanding of what rights pertain in FP programs and how to make them concrete and actionable in FP programs

- Assessing, designing and improving programs

- Monitoring and evaluating programs; holding them accountable

- Creating strategic partnerships; identifying common ground between the public health and rights communities

This is the only framework that merges human rights and public health principles with elements of programming and quality of care frameworks, and that captures a view of a comprehensive, rights-based program in concise, graphic form.

\section{INTENDED AUDIENCES/USERS}

The Framework is intended for a wide range of stakeholders interested in promoting and providing voluntary, rights-based FP services, including policymakers, program managers, service providers, rights advocates, members of civil society organizations, donors, implementing organizations and researchers.

\section{SCOPE \& CONTENT}

Organized as a logic model, the Framework identifies key factors in the country context and details desired inputs or activities for four levels of the health system (policy, service delivery, community and individual) that lead to desired public health/ FP and human rights outputs and outcomes. It is anchored in the right to health (AAAQ), three categories of reproductive rights (to reproductive self-determination, to SRH services, information and supplies; to equality and nondiscrimination) and rights-related principles (PANEL).

\section{DEVELOPMENT PROCESS}

A small Gates Foundation-funded team consisting of FP policy, program and human rights experts created a vision of what a human rights FP program that respects, protects and fulfills HR looks like, and developed a unifying framework that incorporates elements and principles from public health, family planning, holistic healthcare programming, quality of care and human rights. It was informed, and is supported, by systematic reviews of programmatic evidence and of tools related to voluntary, rights-based FP programs (the tools review is described below). Several drafts were shared at numerous convenings of public health, FP and human rights experts and civil society representatives. More than 200 global and country-level stakeholders from more than 25 countries reviewed various drafts. Their input was incorporated into the final document. 
HOW TO USE IT / RESOURCES REQUIRED

It can be used on its own to create understanding of what a comprehensive, rights-based FP program entails. To apply it in practice, it should be used in conjunction with the Users Guide, described below.

\section{WEB LINK}

http://www.futuresgroup.com/files/publications/Voluntary_Rights-

Based_FP_Conceptual_Framework_Paper_FINAL.pdf

http://www.futuresgroup.com/files/publications/Voluntary_Rights-

Based_FP_Conceptual_Framework_Summary_Brief_FINAL.pdf

http://www.futuresgroup.com/files/publications/French_Voluntary_Rights-

Based_FP_Conceptual_Framework_Paper_FINAL.pdf

http://www.futuresgroup.com/files/publications/Hindi_Voluntary_Rights-

Based_FP_Conceptual_Framework_Paper_FINAL.pdf

http://www.futuresgroup.com/files/publications/Spanish_Voluntary_Rights-

Based_FP_Conceptual_Framework_Paper_FINAL.pdf 


\section{5 \\ VOLUNTARY FAMILY PLANNING PROGRAMIS THAT RESPECT, PROTECT, AND FULFILL HUMAN RIGHTS: CONCEPTUAL FRAMEWORK USERS' GUIDE}

\begin{tabular}{|c|c|c|c|}
\hline DATE & PUBLISHER & LANGUAGES & $\begin{array}{c}\text { FUNDING } \\
\text { ORGANIZATION }\end{array}$ \\
\hline 2014 & Futures Group & English & $\begin{array}{l}\text { The Bill and Melinda } \\
\text { Gates Foundation }\end{array}$ \\
\hline
\end{tabular}

\section{TYPE OF RESOURCE}

This companion to the Voluntary, Rights-based Family Planning Conceptual Framework (described above) is a step-by-step "How to" guide that includes all support materials required for conducting an orientation to the framework and for leading stakeholders through a process to apply it in assessing, planning, monitoring and evaluating programs.

\section{PURPOSE}

This Guide enables users to apply the Voluntary, Rights-based FP Framework in practice.

\section{INTENDED AUDIENCES/USERS}

Like the Framework, the Users' Guide is intended for a wide range of stakeholders interested in promoting and providing voluntary, rights-based FP services, including policymakers, program managers, service providers, rights advocates, members of civil society organizations, donors, implementing organizations and researchers.

\section{SCOPE \& CONTENT}

The Guide is a complete resource package consisting of two modules, one for designing and conducting a workshop to introduce and orient stakeholders to the Framework, and one for a more in-depth workshop to apply the Framework in a seven-step process that generates the building blocks for a one-year action plan and a monitoring plan. It includes detailed facilitator guidance and participant workbooks, considerations for follow-up to the planning workshop and recommended next steps for moving quickly to action, plus background materials, supplementary references, tools and resources.

\section{DEVELOPMENT PROCESS}

The Guide was drafted by several members of the Framework development team. A field-test of the first draft was conducted in Uganda in 2014. It involved the MOH, a USAID-funded RH project and a Gates Foundation-funded Implants project. Their feedback was incorporated into the final version.

\section{HOW TO USE IT / RESOURCES REQUIRED}

It can be used in orientations, needs assessments, advocacy, program design and improvement, monitoring and evaluating programs. All resources required are included in the Users' Guide (apart from local policy, strategy and program documents and data).

\section{WEB LINK}

http://www.futuresgroup.com/files/publications/Voluntary_Rights-Based_FP_Users_Guide_FINAL.pdf Additional supporting material available: http://www.futuresgroup.com/resources/publications/voluntary_family_planning_programs_that_respect_protec t_and_fulfill_hu1 


\section{6 \\ CHECKPOINTS FOR CHOICE: AN ORIENTATION AND RESOURCE PACKAGE}

$\begin{array}{cccc}\text { DATE } & \text { PUBLISHER } & \text { LANGUAGES } & \text { FUNDING ORGANIZATION } \\ 2014 & \begin{array}{c}\text { EngenderHealth/ } \\ \text { The RESPOND Project }\end{array} & \text { English } & \text { The William \& Flora Hewlett } \\ & \text { Foundation and USAID }\end{array}$

\section{TYPE OF RESOURCE}

Programming guidance

\section{PURPOSE}

This package provides all materials necessary to organize and conduct a workshop to strengthen the focus of FP programs on clients' rights and contraceptive choices, to strengthen a program's capacity to identify and address vulnerabilities related to full, free and informed choice, and to increase individuals' agency. Unlike other existing resources, it is written from the perspective of how the client experiences family planning programs.

\section{INTENDED AUDIENCES/USERS}

The package is intended for experienced facilitators to lead a workshop for diverse participants, including donors, policymakers, program planners and managers, service providers, staff of technical assistance agencies, and rights and community advocates.

\section{SCOPE \& CONTENT}

The package fills a gap by focusing on the client's perspective, preferences and experiences and on the many factors that affect an individual's ability to make full, free and informed choices about FP. It highlights the need to make FP programs client-centered rather than method-driven and to think critically about the extent to which contraceptive choice is protected in FP programs. It consists of a resource package for a one-day orientation to help FP stakeholders understand concepts related to full, free and informed choice and client-centered programming. Individual session plans, detailed guidance for facilitators, and all necessary support materials, plus a list of related reference materials and tools, are provided.

\section{DEVELOPIMENT PROCESS}

It was developed by a team of EngenderHealth staff and consultants, some of whom were also involved in planning and conducting a consultation of experts in Bellagio in 2012 to explore the intersection of human rights and FP, and in developing the Voluntary, Rights-based FP Conceptual Framework. This package builds upon materials that were developed for the Bellagio consultation and responds to recommendations that came out of the deliberations. It was designed to complement the Voluntary, Rights-based FP Framework. It was pilot-tested with USAID staff in Washington, D.C. and in conjunction with the Voluntary, Rights-based FP Conceptual Framework Users' Guide in Uganda, both in 2014. Revisions based on the pilot- tests were incorporated into the final version.

\section{HOW TO USE IT / RESOURCES REQUIRED}

This is a complete package that can be used alone or in conjunction with other training, assessment or planning activities or tools to strengthen voluntarism, contraceptive choice, human rights and accountability in FP programs. Facilitators are encouraged to modify the workshop plan, selecting individual session to fit within time constraints and to focus on areas of greatest interest to stakeholders.

\section{WEB LINK}

https://www.engenderhealth.org/files/pubs/family-planning/Checkpoints-for-Choice-An-Orientation-andResource-Package.pdf 


\section{A HUMAN RIGHTS-BASED APPROACH TO PROGRAMIMING:}

\section{PRACTICAL IMPLEMENTATION MANUAL AND TRAINING MATERIALS}

\begin{tabular}{|c|c|c|c|}
\hline $\begin{array}{l}\text { DATE } \\
2010\end{array}$ & $\begin{array}{c}\text { PUBLISHER } \\
\text { UNFPA (with Harvard } \\
\text { School of Public Health) }\end{array}$ & $\begin{array}{c}\text { LANGUAGES } \\
-\end{array}$ & $\begin{array}{c}\text { FUNDING ORGANIZATION } \\
\text { UNFPA }\end{array}$ \\
\hline \multicolumn{4}{|c|}{$\begin{array}{l}\text { An in-depth conceptual overview of a human rights-based approach plus "How to" programming guidance and } \\
\text { training materials. }\end{array}$} \\
\hline \multicolumn{4}{|c|}{$\begin{array}{l}\text { This manual provides step-by-step guidance on how to apply a culturally sensitive, gender-responsive, human } \\
\text { rights-based approach to programming in each of UNFPA's three core areas of work: population and development, } \\
\text { reproductive health, and gender. It also covers how to apply such an approach in the context of a humanitarian } \\
\text { emergency. It aims to develop knowledge and provide tools necessary for building national capacity to implement a } \\
\text { human rights-based approach in programming and policies at all levels from an ICPD perspective. The manual can } \\
\text { be used as a stand-alone tool or in conjunction with the accompanying Training Materials (Power Point) as a basis } \\
\text { for conducting a training in human rights-based programming. }\end{array}$} \\
\hline \multicolumn{4}{|c|}{$\begin{array}{l}\text { This manual was designed primarily for use by UNFPA Country Staff, but it can also be useful for UNFPA } \\
\text { implementing partners and others working in the fields of population and development, sexual and reproductive } \\
\text { health and reproductive rights, gender equality and women's empowerment. }\end{array}$} \\
\hline $\begin{array}{l}\text { SCOPE \& Co } \\
\text { The content } \\
\text { Common Ut } \\
\text { of three part } \\
\text { application o } \\
\text { facilitator's } n \\
\text { supported ac } \\
\text { implications. } \\
\text { studies. It of } \\
\text { human right } \\
\text { discriminatio } \\
\text { (availability, } \\
\text { to operation }\end{array}$ & $\begin{array}{l}\text { manual is based on the hur } \\
\text { ding on a Human Rights-b } \\
\text { st covers core concepts of } \\
\text { an rights-based approach, } \\
\text { The document lists the hur } \\
\text { at are inspired by these rig } \\
\text { porates many examples ba } \\
\text { lepth conceptual content a } \\
\text { les of a HRBA (especially } \\
\text { iccountability and Rule of }\end{array}$ & $\begin{array}{l}\text { ased approach } \\
\text { ach (HRBA) } t \\
\text { hhts-based app } \\
d \text { consists of } t \\
\text { at are most } r e \\
\text { ranslates rights } \\
\text { FPA experienc } \\
\text { programming } \\
\text { es of participa } \\
\text { applied progr } \\
\text { vides guidance }\end{array}$ & $\begin{array}{l}\text { the } 2003 \text { UN Statement of } \\
\text { ent Cooperation. It consists } \\
\text { cond provides guidance on } \\
\text { ials which include a } \\
\text { IFPA's work and UNFPA- } \\
\text { to programmatic } \\
\text { s worksheets and case } \\
\text { plaining how each of the core } \\
\text { sion, equality and non- } \\
\text { It also introduces } 3 \mathrm{AQ} \\
\text { les to consider with respect }\end{array}$ \\
\hline
\end{tabular}




\section{DEVELOPMENT PROCESS}

This manual was produced through a collaboration between the Program on International Health and Human Rights, Harvard School of Public Health and the Gender, Human Rights and Culture Branch of the UNFPA

Technical Division, with the involvement of UNFPA staff and outside consultants. It draws from the Action 2 Common Learning Package, which stems from a global UN program designed to strengthen the capacity of country teams to support the efforts of Member States in reinforcing their national human rights promotion and protection systems. There was broad participation during the development process from UNFPA staff members, both at Headquarters and at Country Office level, as well as from other agencies. Four regional training centers played an important role in both the drafting and testing of this manual and training materials.

\section{HOW TO USE IT / RESOURCES REQUIRED}

It is designed to serve both as a 'how to' manual for conducting trainings as well as a reference on using an HRBA. It is self-contained; all necessary materials are included.

\section{WEB LINK}

http://www.unfpa.org/resources/human-rights-based-approach-programming 


\section{THE RIGHT TO CONTRACEPTIVE INFORIMATION AND SERVICES FOR WOMEN AND ADOLESCENTS: BRIEFING PAPER}

\begin{tabular}{|c|c|c|c|}
\hline $\begin{array}{l}\text { DATE } \\
2010\end{array}$ & $\begin{array}{c}\text { PUBLISHER } \\
\text { Center for Reproductive Rights } \\
\text { and UNFPA, New York }\end{array}$ & $\begin{array}{l}\text { LANGUAGES } \\
\text { English }\end{array}$ & $\begin{array}{c}\text { FUNDING ORGANIZATION } \\
\text { UNFPA }\end{array}$ \\
\hline \multicolumn{4}{|c|}{$\begin{array}{l}\text { TYPE OF RESOURCE } \\
\text { An overview of applicable human rights and program guidance for how to put a human rights-based approach into } \\
\text { practice. }\end{array}$} \\
\hline \multicolumn{4}{|c|}{$\begin{array}{l}\text { This briefing paper lays out a conceptual foundation and provides practical guidance for how to integrate human } \\
\text { rights into programs and policies related to contraceptive information and services. }\end{array}$} \\
\hline \multicolumn{4}{|c|}{$\begin{array}{l}\text { INTENDED AUDIENCES/USERS } \\
\text { Activists, scholars, UN Agencies, NGOs, governments and other actors working in the area of sexual and } \\
\text { reproductive health. }\end{array}$} \\
\hline \multicolumn{4}{|c|}{$\begin{array}{l}\text { The paper focuses specifically on the right to contraceptive information and services. It includes an overview of the } \\
\text { problem of lack of access to contraceptive information and services for women and adolescents, lays out the } \\
\text { human rights that underpin the right to access contraceptive information and services, and offers brief suggestions } \\
\text { for how to put a human rights-based approach into practice. The Appendix cites specific regional and international } \\
\text { treaty provisions related to contraceptive access which buttresses accountability. }\end{array}$} \\
\hline \multicolumn{4}{|c|}{$\begin{array}{l}\text { This is a joint product of the Center for Reproductive Rights and UNFPA. It was conceptualized by Center and } \\
\text { UNFPA staff and was written by a team of lawyers under the guidance of UNFPA technical staff. }\end{array}$} \\
\hline \multicolumn{4}{|c|}{ HOW TO USE IT / RESOURCES REQUIRED } \\
\hline $\begin{array}{l}\text { WEB LINK } \\
\text { http://wwy }\end{array}$ & $\mathrm{g} /$ sites/default/files/resource & aception.p & \\
\hline
\end{tabular}




\section{VOLUNTARY FAMILY PLANNING PROGRAMS THAT RESPECT, PROTECT, AND FULFILL HUMAN RIGHTS: A SYSTEMATIC REVIEW OF TOOLS}

DATE

2013
PUBLISHER

Futures Group, Washington DC

\section{LANGUAGES}

English
FUNDING ORGANIZATION

The Bill and Melinda Gates

Foundation

\section{TYPE OF RESOURCE}

Compilation and synthesis of tools that support rights-based programming.

\section{PURPOSE}

This document offers synopses of tools that can be applied to support a rights-based approach in different stages of program assessment, planning and implementation.

\section{INTENDED AUDIENCES/USERS}

A broad range of FP program stakeholders, including donors, policymakers, managers, service providers and community members.

\section{SCOPE \& CONTENT}

This systematic review is a companion to the Voluntary, Rights-based FP Conceptual Framework. It compiles and synthesizes training and assessment tools, frameworks, methodologies, implementation guides, and job aids that support and promote the fulfillment of rights at the policy, service, community, and/or individual levels. It includes 150 documents that met defined selection criteria, and identifies where additional resources are required.

\section{DEVELOPMENT PROCESS}

These reviews were undertaken by the same team that developed the Voluntary, Rights-based, FP Conceptual Framework comprised of staff and consultants from the Futures Group and EngenderHealth, with input from a wide range of reviewers. The search strategy was guided by a series of questions related to what a successful voluntary, right-based FP program should include. The evidence search included principles approaches and intervention studies. The tools review used a long list of search terms to identify training tools, assessment tools, frameworks, methodologies, implementation guidance and job aids. Both documents are structured in alignment with the architecture of the framework, which recognizes four levels of the health system (policy, service delivery, community and individual).

\section{HOW TO USE IT / RESOURCES REQUIRED}

These are reference documents that don't require any particular skills or additional resources.

\section{WEB LINK}

http://www.futuresgroup.com/files/publications/VRBFP Tools_paper_FINAL.pdf 


\section{REPRODUCTIVE RIGHTS ARE HUMAN RIGHTS. A HANDBOOK FOR NATIONAL HUMAN RIGHTS INSTITUTIONS}

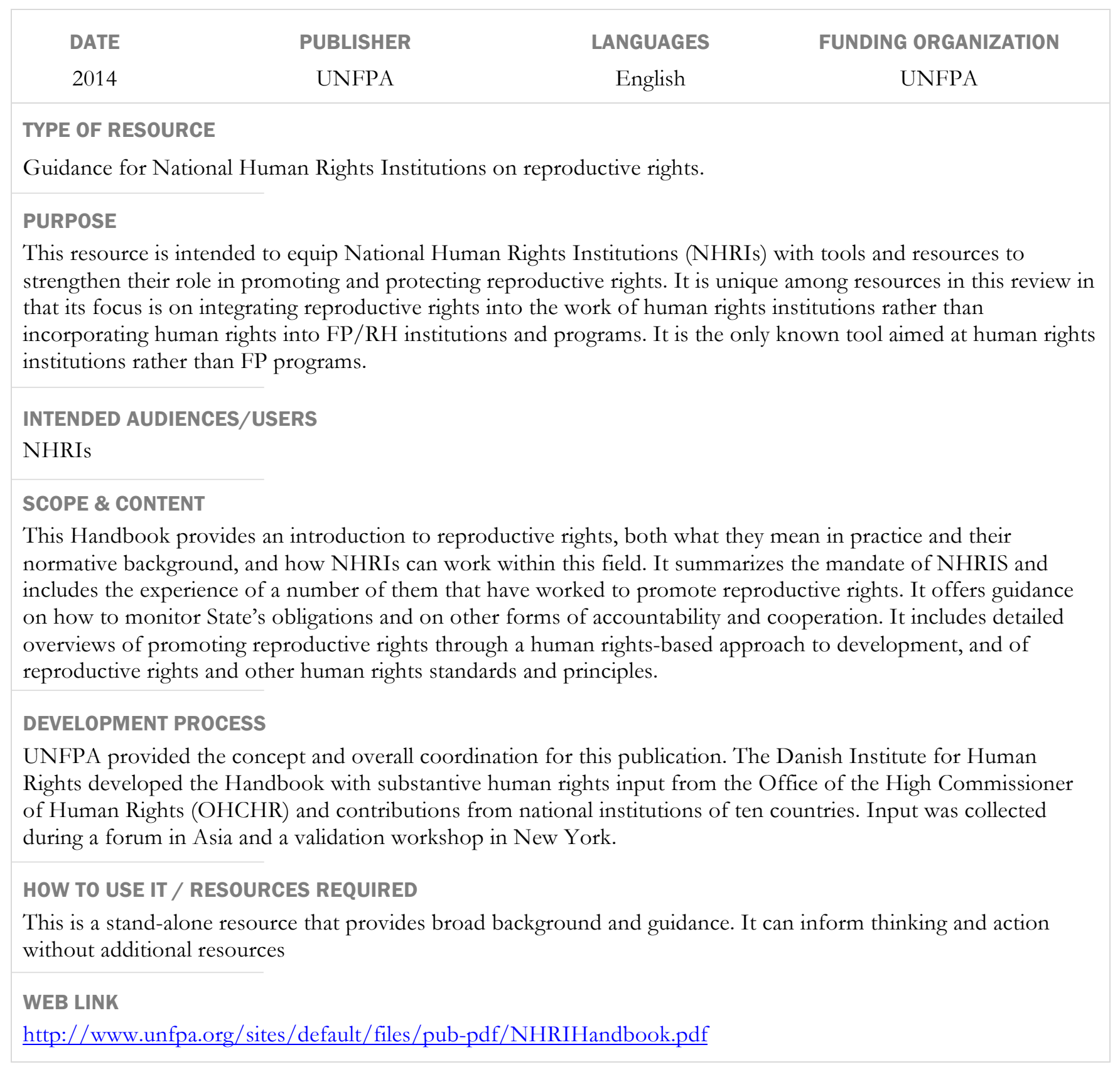




\section{References}

Center for Reproductive Rights. 2009. Reproductive Rights are Human Rights 2009. New York: Center for Reproductive Rights.

Center for Reproductive Rights and UNFPA. 2010. The Right to Contraceptive Information and Services for Women and Adolescents: Briefing Paper. New York: Center for Reproductive Rights.

Cottingham, J., Germain, A., and Hunt, P. 2012. Use of human rights to meet the unmet need for family planning. The Lancet 380(9837): 172-180.

Department for International Development (DFID). 2005. How to Reduce Maternal Deaths: Rights and Responsibilities. London: DFID, Policy Division.

Erdman, J. N., and Cook, R. J. 2008. Reproductive Rights. International Encyclopedia of Public Health. Editor-inChief: Kris. Oxford, Academic Press: 532-538.

FP202 Rights and Empowerment Working Group. 2014. Family Plannign 2020: Rights and Empowerment Principles for Family Planning. Washington, DC: FP2020.

Gruskin, S., Mills, E.J., and Tarantola, D. 2007. "History, principles, and practice of health and human rights." The Lancet 370(9585): 449-455.

Hardee, K., K. Newman, L. Bakamjian, J. Kumar, S. Harris, M. Rodriguez, and K. Willson. 2013. Voluntary Family Planning Programs that Respect, Protect, and Fulfill Human Rights: A Conceptual Framework. Washington, DC: Futures Group.

International Planned Parenthood Federation (IPPF). 1996. IPPF Charter on Sexual and Reproductive Rights. London: IPPF.

Kumar, J., L. Bakamjian, H. Connor, and S. Harris. 2013. Voluntary Family Planning Programs that Respect, Protect, and Fulfill Human Rights: A Systematic Review of Tools. Washington, DC: Futures Group and EngenderHealth.

Kumar, J., L. Bakamjian, S. Harris, M. Rodriguez, N. Yinger, C. Shannon and K. Hardee. 2014. Voluntary Family Planning Programs that Respect, Protect, and Fulfill Human Rights: Conceptual Framework Users' Guide. Washington, DC: Futures Group.

The RESPOND Project. 2014. Checkpoints for choice: An orientation and resource packeage. New York: EngenderHealth/The RESPOND Project.

Office of the High Commissioner for Human Rights (OHCHR). 2006. Frequently Asked Questions on a Human Rights-based Approach to Development Cooperation. New York and Geneva: OHCHR.

United Nations Population Fund (UNFPA). 2010. A Human Rights-based Approach to Programming/Practical Implementation Manual and Training Materials. New York: UNFPA and Boston: Harvard School of Public Health. 
UNFPA. 2014. Reproductive Rights are Human Rights. A Handbook. for National Human Rights Institutions. New York: UNFPA.

UNFPA, Danish Institute for Human Rights and UNOHCRH. 2014. Reproductive Rights are Human Rights. A Handbook for National Human Rights Institutions. New York: UNFPA.

UNFPA and Harvard School of Public Health. 2010. A Human Rights-based Approach to Programming: Practical Implementation Manual and Training Materials. New York: UNFPA.

WHO and UNFPA. 2015. Ensuring Human Rights Within Contraceptive Service Delivery: Implementation Guide. Geneva: WHO.

WHO. 2014. Ensuring Human Rights in the Provision of Contraceptive Information and Services. Geneva: WHO. 


\section{The Evidence Project}

Population Council

4301 Connecticut Avenue, NW, Suite 280

Washington, DC 20008 USA

tel +12022379400

evidenceproject.popcouncil.org 